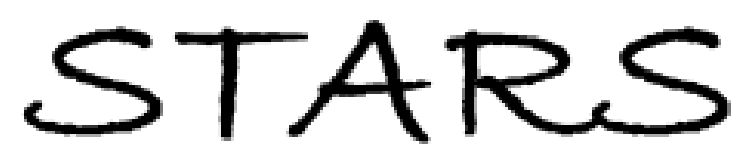

University of Central Florida

STARS

6-1-2010

\title{
Examining the Relationship Among Service Recovery, Affective Commitment, Calculative Commitment, And Trust for E-Travel Retailers
}

Khaldoon Nusair

University of Central Florida, Khaldoon.Nusair@ucf.edu

Part of the Hospitality Administration and Management Commons, and the Tourism and Travel Commons

Find similar works at: https://stars.library.ucf.edu/rosenscholar University of Central Florida Libraries http://library.ucf.edu

This Paper is brought to you for free and open access by the Rosen College of Hospitality Management at STARS. It has been accepted for inclusion in Rosen Faculty Scholarship and Creative Works by an authorized administrator of STARS. For more information, please contact STARS@ucf.edu.

\section{Original Citation}

Nusair, K. (2011)."Examining the relationship among service recovery, affective commitment, calculative commitment, and trust for e-travel retailers". The role of e-service recovery in building long-term customer relationships." Journal of Information Technology and Tourism, 12, 317-330.

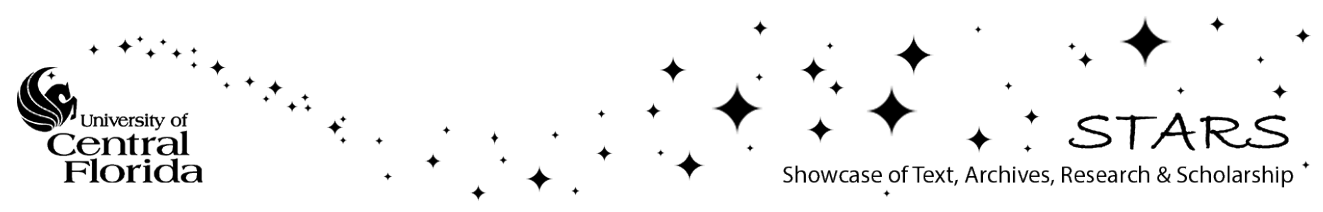




\title{
EXAMINING THE RELATIONSHIP AMONG SERVICE RECOVERY, AFFECTIVE COMMITMENT, CALCULATIVE COMMITMENT, AND TRUST FOR E-TRAVEL RETAILERS
}

\author{
KHALDOON “KHAL” NUSAIR \\ Rosen College of Hospitality Management, University of Central Florida, Orlando, FL, USA
}

\begin{abstract}
There is a gap in the literature with respect to studies that examined the importance of service recovery for Generation Y customers in an online travel context. This study examines various dimensions of commitment important to the development and maintenance of enduring relationships with Generation Y. The theoretical foundations for this study are based on social exchange theory, commitment-trust theory, and organizational commitment theory. The results of the study shows that affective commitment and trust are the most important constructs for building longterm relationships following service recovery; on the other hand, calculative commitment had negative impact on trust. The implications of these findings for both research and practitioners are discussed in the final section of the study.
\end{abstract}

Key words: Travel planning; Trust; Commitment; Online service recovery; Generation Y

\section{Introduction}

The online travel agencies account for more than half of online travel sales in the major categories of online tickets, hotel rooms, and car rentals (Rao \& Smith, 2005). The commonly offered products by online travel retailers are airline travel, hotel accommodations, car rentals, and cruise and vacation packages. According to a study, 95\% of web users have searched the Internet to gather travel related information (Lehto, Kim, \& Morrison, 2006). Moreover, a report by Forrester Research in 2007 has indicated that nearly 40 million US households booked travel-related products on the Internet, spending $\$ 86$ billion on airline tickets, lodging, cars, intercity rail, cruises, and packages (Harteveldt, 2007).

The characteristics of Generation Y (Gen Y) customers are significantly different from the previous generational cohorts (Reisenwitz \& Iyer, 2009). Although the world economy has been struggling through a recession, it seems to have had no effect on Gen Y's spending, making them compulsive shoppers for the long term ("Young Compulsive Shoppers," 2009). A recent study has indicated that Gen Y has been recognized as a substantial market segment that uses the Internet for $15 \%$ of their spending (Sullivan \& Heitmeyer, 
2008). In their efforts to attract new customers or to keep the existing ones, online travel agents need to devote considerable attention to the Gen Y market segment.

The importance of e-commerce for developing long mutual benefits between buyers and sellers has been emphasized in marketing literature (Aladwani, 2001; Eastlick, Lotz, \& Warrington, 2006; Petre, Minocha, \& Roberts, 2006; Thorbjornsen, Supphellen, Nysveen, \& Pedersen, 2002). Delivering service quality not only contributes to customer satisfaction (Thirumalai \& Sinha, 2005), but also generates loyalty (Boyer \& Hult, 2005). However, if a problem arises during the exchange between buyers and sellers, e-travel retailers must be aware of the importance of service recovery in the resolution of this problem. Research showed that the majority of customers surveyed were dissatisfied with vendors' service recovery efforts and this dissatisfaction affected the intention to repatronize the online business (Holloway \& Beatty, 2003). Recovery measures are extremely important for an online travel retailer because customers are just one click away from switching to another retailer. Despite the recognition of the fact that service recovery research studies in e-commerce have received increasing attention from researchers, the attraction between service recovery and Gen Y customers has received little attention from marketing academics.

Many research studies have built upon commitment as mediator in relationships (Fullerton, 2005; Morgan \& Hunt, 1994). Commitment has been viewed as an implicit or explicit pledge of continuity between relationship partners (Dwyer, Schurr, $\&$ Ho, 1987). Allen and Meyer (1990) conceptualized commitment in three dimensions namely, affective, calculative, and normative. Theoretically, affective commitment, calculative commitment, and normative commitment are distinct behaviors that customers can bond to an online travel agent. In addition to commitment, trust has been considered an important construct for the development of long-term relationships with vendors. According to Morgan and Hunt (1994), a critical complement of trust in exchange relationships is commitment. They indicated that parties will seek only trustworthy partners.

High-quality relationships between Gen Y cus- tomers and e-travel retailers bind the members to each other in such a way that they maintain successful long-term beneficial relationships. It is important to know how service recovery will impact the relationship between Gen Y and e-travel retailers. Recovery measures are extremely important because dissatisfied customers may: exit the relationship, switch to another service provider, and engage in negative word-of-mouth communications (Singh, 1998). Although the importance of a proper understanding of service recovery has been demonstrated in many studies, very little is known about service recovery and its impact on the relationship with the e-travel vendor, specifically for Gen $Y$ customers. In fact, many studies treated Gen Y, Gen X, and baby boomers as a single target market segment (Forbes, Kelley, \& Hoffman, 2005; Reed, 2007). However, there is variability in customer behavior among several population groups (e.g., elderly, baby boomers, and younger generations) (Mohammadian \& Bekhor, 2008). Leaning on the foundation of social exchange theory, organizational commitment theory, and commitment-trust theory as prominent theories for the formation, development, and maintenance of longlasting relationships, this study has two objectives: (1) To examine the impact of service recovery on the two dimensions of commitment namely, affective and calculative; (2) To investigate the impact of affective and calculative commitments on trust. The findings of this study will give the e-travel marketers more direction in better addressing the needs of Gen $\mathrm{Y}$ and will help them to develop service recovery strategies targeted solely for Gen Y.

\section{Generation Y}

Generation Y (or "Millennials") are taking digital life in their stride (Bue-Said, 2008). Members of Gen Y were born between 1981 and 1994; this time frame identifies Gen Y as customers between 16 and 29 years old in 2009 (Hahn, Upchurch, \& Wang, 2008). There were 72 million Americans born between these years, which makes the Millennial generation almost as large as the Baby Boom generation (Weiss, 2003). Unlike any other generation cohort, more than $70 \%$ of Gen Y income is disposable, with the majority going to entertainment, travel, and food (McCrindle, 2002). 
Their estimated disposable income is between $\$ 115$ billion and $\$ 187$ billion, and their indirect purchasing power totals around $\$ 500$ billion (Niedt, 2004). In fact this generation cohort is described as the most consumption oriented of all generations (Wolburg \& Pokrywczyniski, 2001).

Gen $\mathrm{Y}$ possesses a high level of technical skills with $67 \%$ using computers frequently (Bensley \& Whitney, 2004). Gen Y has become a consumer culture as a result of their technological innovation (Blakewell \& Mitchell, 2003). It is the first hightech generation and it has access to more credit than any predated generation (Weiss, 2003). As a large segment of Gen Y, 5.9 million full-time students in 4-year institutions spent $\$ 9.2$ billion during 2002, up 27\% from 1997 (Yin, 2003). Additionally, Lester, Forman, and Loyd (2005) in their study that included 780 university students indicated that over $95 \%$ of the university students used the Internet and over $91 \%$ of them had purchased products online. As their buying power grows, these emerging adults learn consumer behavior patterns that influence them in later life (Y. Kim, Sullivan, \& Forney, 2007). This ethnically diverse group not only buys for themselves, but also influences their family purchase decisions (Sullivan \& Heitmeyer, 2008).

\section{Theoretical Background}

The theoretical foundations of this study are three prominent marketing theories, social exchange theory, organizational commitment theory, and commitment-trust theory. These theories are important for developing and maintaining longterm relationships between Gen Y customers and the travel business in the online context.

\section{Service Recovery}

Social exchange theory provides the theoretical foundation for service recovery research studies. This theory emphasizes the equal partnership between buyers and sellers in an exchange (Oliver, 1999). Specifically, social exchange theory has identified three dimensions that influence how customers evaluate exchanges namely: (1) distributive justice, which involves resource allocation and the perceived outcome of exchange (Deutsch, 1975); (2) procedural justice, which involves the means by which decisions are made and conflicts are resolved (Thibaut \& Walker, 1975); and (3) interactional justice, which involves the manner in which information is exchanged and outcomes are communicated (Bies \& Shapiro, 1987).

Service recovery refers to activities in which a business engages to address a customer complaint regarding a perceived service failure (Grönroos, 1988). Service recovery includes the issues related to providing products and services such as the fulfillment issues; website issues; customer servicerelated issues; and security and risks with respect to disclosure of customers' personal data (Mollenkopf, Rabinovich, Laseter, \& Boyer, 2007). Findings from the Jupiter Executive Survey revealed that the majority of customers $(57 \%)$ expressed that the speed of a retailer's response to customer service e-mail inquiries, as one form of service recovery, would affect their decision to make future purchases from that website (B. Cox, 2002). Service recovery requires positive actions to affect customer behavior and can ultimately strengthen customers' commitment to enterprises. Ensuring the service from the e-retailer provides an opportunity to redress dissatisfaction (Andreassen, 2001). Hess, Ganesan, and Klein (2003) suggest that strong relationships between buyers and suppliers can shield a service firm from the negative impact of a service recovery.

Tax and Brown (1998) stated, "The greatest barrier to effective service recovery and organizational learning is the fact that only 5 percent to 10 percent of dissatisfied customers chose to complain following a service failure" (p. 77). In addition, Holloway and Beatty (2003) indicated that the majority of surveyed customers were dissatisfied with the recovery attempts and this dissatisfaction affected customers future purchase intentions. If there is a consistent problem accessing a website or while using it, then a customer should complain, but rather they are more likely to switch to another service provider's website (Cox \& Dale, 2001). A study conducted by the Boston Consulting group indicates that $48 \%$ of respondents cite slow response time as the main reason for abandoned online transactions (Teeter \& Schointuch, 2000).

In response to service recovery, service providers take actions and implement activities to return 
"aggrieved customers" to a state of satisfaction (Grönroos, 1988). Thus, service recovery is considered as a retention strategy. Also, service recovery has a direct relationship with a number of behavioral outcomes such as trust, repurchase intentions, commitment, word of mouth, and loyalty, which all play a crucial role in the success of e-retailers (Bitner, Brown, \& Meuter, 2000; Blodgett, Hill, \& Tax, 1997; Goodwin \& Ross, 1992; Mohr \& Bitner, 1995).

\section{Organizational Commitment Theory}

Commitment theory was originated by Becker in 1960. Commitment is a central construct in the development and maintenance of marketing relationships because it is a key psychological force that links the buyer to the seller (Bansal, Irving, $\&$ Taylor, 2004). Bowen and Shoemaker (2003) further define commitment as the belief that an ongoing relationship is so important that the partners are willing to work at maintaining the relationship and are willing to make short-term sacrifices to realize long-term benefits. Although Allen and Meyer (1990) examined commitment in organizational settings, commitment is a broad construct that extends to a variety of relationships (e.g., customer-vendor relationships, relationship between businesses, etc.). Allen and Meyer identified three different types of commitment, namely affective commitment, "the desire to belong to the organization"; calculative commitment, "a belief that leaving the organization will be costly"; and normative commitment, "the moral obligation to stay in a relationship." Of these, affective commitment and calculative commitment are most recognized in literature (Fullerton, 2003; Harrison-Walker, 2001) and also seem to be the most relevant for building relationships between buyers and sellers. While these two forms of commitment have been widely studied, very few researchers have examined normative commitment. The rationale for limited work on normative commitment is due to the fact that normative commitment is usually highly correlated with affective commitment and some researchers have questioned the extent to which it is a distinct construct (O'Reilly, Chatman, \& Caldwell, 1991). Thus, this study will focus only on affective commitment and calculative commitment.

\section{Affective Commitment}

Affective commitment is a well-studied construct in relationship marketing (Fullerton, 2003; Gilliland \& Bello, 2002). Affective commitment emerges as a consequence of the emotional feelings and the closeness between two parties involved in a relationship (Meyer, Allen, \& Smith, 1993). More specifically, it assumes that both parties will likely be interested in continuing the relationship in the long term (Anderson \& Weitz, 1992). Buchanan (1974) conceptualized affective commitment as a "partisan, affective attachment to the goals and values of the organization, to one's role in relation to the goals and values, and for the organization for its own sake, apart from its purely instrumental worth" (p. 533). According to this view, an affectively committed channel member desires to continue a relationship because he/she likes the partner and enjoys the partnership (Buchanan, 1974). Affective commitment is reflected by feeling committed to the vendor (Garbarino \& Johnson, 1999; Morgan \& Hunt, 1994; Sharma \& Patterson, 2000) and believing that the vendor is the best alternative (Wong \& Sohal, 2002). The findings of W. Kim, Han, and Lee (2001) indicated that higher commitment leads to positive word of mouth and repeat purchase.

\section{Calculative Commitment}

Calculative commitment is based on an economic rationale. A Gen Y customer will be committed to the relationship due to the fact that the value of the resources invested in the relationship would be substantially decreased if the individual chose to finish the relationship and start another one. Calculative commitment is caused by the existence of sunk and switching costs and also arises when there are no attractive alternatives to the established relationship (Anderson \& Weitz, 1992).

In a similar vein, De Ruyter, Moorman, and Lemmink (2001) pointed out that because calculative commitment is based on cost-benefit considerations, it has been shown that a positive relationship exists between perceived switching costs and risks on one hand and the calculative dimension of commitment on the other. Additionally, Gilliland and Bello (2002) suggested that the calculative dimension of commitment measures to what 
extent a customer's attachment to a supplier is based on structural ties, which is focused on getting the job done. This binding is experienced as an understanding of the sacrifices associated with termination.

\section{Commitment'Trust Theory}

Morgan and Hunt (1994) stated that both commitment and trust are essential for successful relationship marketing. Commitment and trust are key because they encourage marketers to: (1) work at maintaining relationship by cooperating with exchange partners, (2) resist attractive short-term alternatives in favor of the expected long-term benefits, and (3) feel secure in taking risks with relationship partners without the concern that their partners will act opportunistically.

Morgan and Hunt (1994) hypothesized that exchange partners will be more committed to their relationships when they possess shared values. They defined shared values as "the extent to which partners have beliefs in common about what behaviors, goals, and policies are important or unimportant appropriate or inappropriate and right or wrong" (p. 25). Morgan and Hunt (1994) believe that when companies focus towards building relationships with customers by embracing high standards and allying oneself with exchange partners having similar values, relationship commitment and trust develop. In their study of commitmenttrust relationships, Morgan and Hunt (1994) found that shared values were the direct precursor of both relationship commitment and trust influencing them both directly. According to relationship marketing theory, trust is integral to the success of any business relationship (Berry, 1995).

Empirical support for the positive main effect of trust on affective commitment has been provided in marketing channels by Anderson and Weitz (1992) and Morgan and Hunt (1994). Although these studies both refer to commitment as a multidimensional construct, their operationalizations reflect primarily affective commitment. Trust is central to interpersonal and commercial relationships because it is crucial wherever risk, uncertainty, or interdependence exist (McKnight \& Chervany, 2002). These conditions flourish in many settings, but thrive in socially distant rela- tionships. Researchers have found trust to be important to both virtual teams and e-commerce. As increased transaction complexity makes conditions more uncertain, as is the case in computer-mediated commerce, the need for trust grows (McKnight \& Chervany, 2002).

\section{Model Development and Research Hypotheses}

Given the importance of commitment in the development of relationships, it is vital to examine which commitment component is important for the development of long-term relationships following service recovery efforts. This article proposes a model to examine the causal relationships among service recovery, affective commitment, calculative commitment, and trust in e-travel context as shown in Figure 1. In the following section the hypothesized model will be discussed.

\section{Commitment and Trust}

Trust is defined as the integrity, honesty, and competence that one partner perceives of another (Morgan \& Hunt, 1994). Both commitment and trust are important for the development of business relationships. According to Morgan and Hunt, a critical complement of trust in exchange relationships is commitment. Similarly, Molm, Takahashi, and Peterson (2000) indicated that affective commitment arises from the same process that generates trust. It can be argued that high level of affective commitment and a strong desire to stay in a relationship leads to trust (Anderson \& Weitz, 1992). On the contrary, Geyskens, Steenkamp, Scheer and Kumar (1996) reported a negative relationship between trust and calculative commitment. When the relationship with a travel firm is based on calculative commitment, there will be less reason to trust the relationship because calculative commitment is based on cost-benefit analysis. Thus, the following hypotheses are proposed:

$\mathrm{H} 1$ : Affective commitment is positively related to trust.

$\mathrm{H} 2$ : Calculative commitment is negatively related to trust.

\section{Service Recovery, Commitment, and Trust}

In the context of service recovery, a demonstration of reliability and trustworthiness through re- 


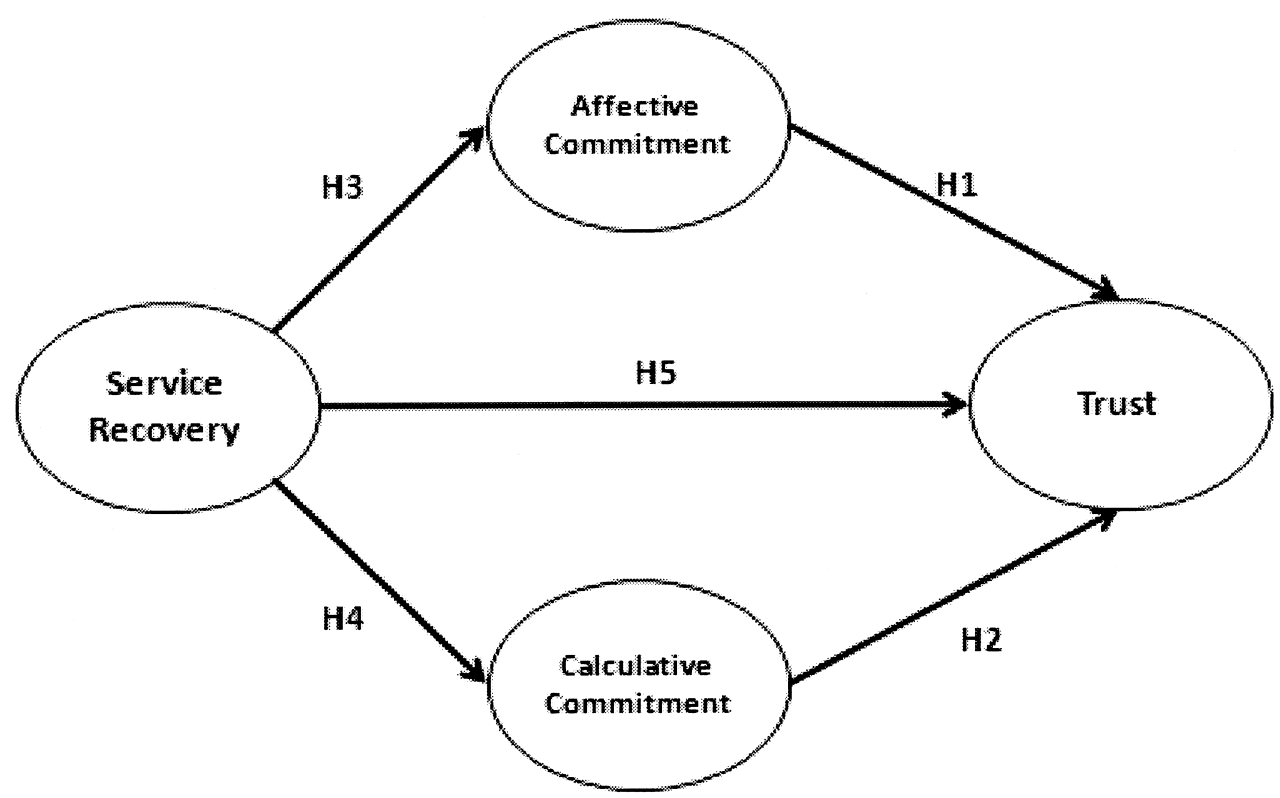

Figure 1. Model of commitment for Generation Y.

sponsible service recovery efforts will increase the favorable evaluation of an online travel service provider. A positive service recovery encounter may improve customers' commitment. There is an empirical support for the proposition that service recovery is tied closely to relationship marketing (Tax, Brown, \& Chandrashekran, 1998). Excellent service recovery can enhance relationships (Andreassen, 2001) while poorly handled service recovery has the potential for destroying loyalty (McDougall \& Levesque, 2000). Tax et al. (1998) confirmed that service recovery is positively related to customer commitment. However, no previous studies have examined the direction of the relationship between service recovery and calculative commitment. Additionally, research suggests that service recovery handling is strongly associated with trust (Kelley \& Davis, 1994). Therefore, the following hypotheses are suggested:

H3: Service recovery is positively associated with affective commitment.

H4: There is a positive relationship between service recovery and calculative eommitment.

H5: Service recovery is positively associated with trust.

\section{Methodology}

This study examines the impact of service recovery on commitment and investigates the impact of affective and calculative commitments on trust. The findings of the study will help e-travel business to better address the needs of Gen Y through the development of service recovery strategies targeted solely for Gen Y. In this study, five posited research hypotheses will be tested. In total, there are four latent variables: service recovery, affective commitment, calculative commitment, and trust.

\section{Measures and Sample}

All research constructs were adopted from previous studies and were measured using multipleitem, 7-point Likert scales with "strongly disagree" and "strongly agree" anchoring the scale. SEM methodology using 7-point Likert scale measures has been widely used in tourism research (Chi \& Qu, 2008; Huang, Chou, \& Lin, 2010). Service recovery was assessed using a five-item scale adopted from Parasuraman, Zeithaml, and Malhorta (2005). Affective commitment was measured using a three-item scale measure and calculative commitment was measured with a four-item 
scale measure, both adopted from Allen and Meyer (1990). Finally, trust was measured using a four-item scale adopted from Morgan and Hunt (1994) (see Table 1). To avoid vague responses and lapses in memory, respondents were asked to recall their last online search/purchase transaction they used for travel purposes. Also, respondents were asked to respond to service recovery questions if they had experienced a problem with their transaction. If the respondent did not have an issue that required service recovery, then he/she was directed to stop participating in the study. Gen Y between the ages of 19 and 25 are major market segment with purchasing power of $\$ 200$ billion (Gardyn, 2002). This age cluster is representative of universal characteristics of majority of college students at most universities in the US. Thus, traditional undergraduate students across several disciplines at a major Midwestern university were se- lected as target population for this study. To eliminate any bias related to academic subject matters, a general education course was chosen for this study. This course is taken by most undergraduate students from different colleges across the university. Typically, total enrollment in this class is about 1,800 students per semester offered as five different sections of 400 students taught in an auditorium. Because participation in this study was voluntary, some students chose not to participate in the study. Thus, a total of 234 questionnaires were left for data analysis. Students were given an academic incentive of five extra credit points out of 1,000 total points for the course for participating in the study.

\section{Data Analysis}

Data were analyzed using: (1) a confirmatory factor analysis was used as a first step to assess

Table 1

Questionnaire Items

\begin{tabular}{lll}
\hline Constructs & Origin/Context & Question Items
\end{tabular}

Service recovery

Affective commitment in an organizational setting

Calculative commitment Allen and Meyer (1990); examined commitment in an organizational setting scale for assessing websites' service quality
Parasuraman et al. (2005); used a multiple-item 1. This site offers a meaningful guarantee.

2. This site tells me what to do if my transaction is not processed.

3. This travel site takes care of problems promptly.

4. This site has customer service representatives available online.

5. This site offers the ability to speak to a live person if there is a problem.

1. It is easy to become attached to this travel website.

2. This travel site has a great deal of attraction for me.

3. This travel site has a great deal of personal meaning for me.

1. I am afraid something will be lost if I stop using this travel website.

2. To stop using this travel website would require considerable personal sacrifice.

3. Some aspects of my life would be affected if I stop using travel website.

4. One of the few serious consequences of stop dealing with this travel website would be the scarcity of available alternatives (other travel websites).

Trust

Morgan and Hunt (1994); examined relationship marketing
1. This travel website is perfectly honest and truthful.

2. This travel site can be trusted completely.

3. This travel site can be counted on.

4. This travel site has high integrity. 
the measurement model; (2) a structural model was used to test the hypotheses. The following goodness-of-fit indices were used to evaluate the measurement model for both CFA and SEM: chisquare/ $d f$ ratio, CFI, GFA, AGFA, NFI, RFI, IFI, and RMSEA (Schumacker \& Lomax, 2004). Data were analyzed using the statistical software SPSS 17 and Lisrel 8.

\section{Results}

The listwise deletion method was used to deal with missing data (Schumacker \& Lomax, 2004). As shown in Table 2, all constructs had reliability coefficients greater than 0.70 as suggested by Hair, Anderson, Tatham, and Black (1998). The bulk of the sample $(51.5 \%)$ were within the age group of 21-22, $29.5 \%$ were within the age group of $19-20,10.7 \%$ were within the age group of $23-$ $24,3.3 \%$ were within the age group of 25-26, $4.7 \%$ were older than 27 , while only $0.3 \%$ were younger than 19. Most students $(97.4 \%)$ were fulltime undergraduate students; 84.4 of the sample were Caucasian and $74.5 \%$ were females. With respect to online spending for travel products and services over the past year, nearly $21.2 \%$ of the sample spent $\$ 1,000$ or more; $13.4 \%$ spent between $\$ 799$ and $\$ 999$, and only 3.0\% spent under
$\$ 100$. Related to the frequency of travel, $44.9 \%$ of the sample traveled once a year, $27.8 \%$ traveled once every 6 months, $21.8 \%$ traveled every 3 months, and $5.5 \%$ traveled once a month. Also, subjects' favorite websites were Expedia.com, Orbitz.com, Trevelocity.com, Cheaptickets.com, and Hotels.com, respectively.

\section{The Measurement Model (CFA)}

Confirmatory factor analysis (CFA) was used to estimate the measurement model using the maximum likelihood method of estimation. The goodness-of-fit measures were used to assess the overall model fit. As indicated by the results of the study, the overall fit indices for the proposed model were acceptable, with chi-square/ $d f$ equal to 2.1, RMSEA of 0.070 , NFI of 0.95 , CFI of 0.97 , GFI of 0.91 , AGFI of 0.88 , IFI of 0.97 , and RFI of 0.94 (Hair et al., 1998).

\section{Evaluating the Measurement Model}

As a second step to our data analysis, the measurement model was evaluated for reliability using convergent validity and discriminant validity. Table 2 shows that the reliability of the constructs ranged from 0.79 to 0.91 , which is an acceptable

Table 2

Measurement Model Results

\begin{tabular}{llccc}
\hline \multirow{2}{*}{ Construct } & Variables & $\begin{array}{c}\text { Standardized } \\
\text { Loadings }\end{array}$ & $\begin{array}{c}\text { Construct } \\
\text { Reliability }\end{array}$ & AVE \\
\hline Service recovery (SRVREC) & SRVREC1 & 0.82 & 0.60 & \\
& SRVREC2 & 0.76 & & \\
& SRVREC3 & $0.37^{\mathrm{a}}$ & & \\
& SRVREC4 & 0.62 & & \multirow{2}{*}{0.70} \\
& SRVREC5 & 0.67 & & \\
Affective commitment (AFCOM) & AFCOM1 & 0.83 & 0.85 & \multirow{2}{*}{0.72} \\
& AFCOM2 & 0.82 & & \\
Calculative commitment (CALCOM) & AFCOM3 & 0.75 & & \\
& CALCOM1 & 0.80 & 0.90 & \\
& CALCOM2 & 0.92 & & \\
& CALCOM3 & $0.42^{\mathrm{a}}$ & & \\
Trust (TRUST) & CALCOM4 & 0.84 & & \\
& TRUST1 & 0.83 & 0.91 & \\
& TRUST2 & 0.87 & & \\
& TRUST3 & 0.86 & & \\
& TRUST4 & 0.80 & & \\
\hline
\end{tabular}

${ }^{\mathrm{a}}$ Removed due to low item loadings. 
reliability for all the constructs (Chen \& Hitt, 2002). Also, the average variance extracted (AVE) was used to assess convergent validity (Garbarino \& Johnson, 1999). AVE values ranged from 0.60 to 0.73 (Table 2), which exceeded the 0.50 threshold value suggesting no violation to convergent validity. Finally, comparing interconstruct correlations with the square root of AVE indicated that discriminant validity is not an issue (Fornell \& Larcker, 1981) (see Table 3).

\section{The Structural Equation Model}

Similarly, the goodness-of-fit indices were used to evaluate the structural model. The overall fit indices for the SEM model was acceptable, with chi-square/ $d f$ equal to 2.12, RMSEA of 0.075 , NFI of 0.94 , CFI of 0.97 , IFI of 0.97 , and RFI of 0.93 . Therefore, the previous goodness-of-fit indices for the SEM model suggest an acceptable fit. In terms of the variance explained, calculative commitment explained $9 \%$ of the variance, affective commitment explained $26 \%$ of the variance, and trust explained $48 \%$ of the variance (Fig. 2).

\section{Discussion}

The results reported in this research emphasize a number of important findings (Figure 2, Table 4). This study showed that affective commitment had a significant positive impact on trust (H1) (path coefficient $=0.34$ ). Relational marketing considers trust a vital concept. The findings regarding the relationship between the affective commitment and trust were in line with the results from the study of Sui and Baloglu (2003). This outcome demonstrated that when the base for this relationship is the emotional attachment to the travel vendor, commitment will result in the increased confidence in the travel supplier. Thus, the higher

Table 3

Discriminant Validity Matrix

$1 \quad 2 \quad 3$

4

\begin{tabular}{lcccr}
\hline TRUST & $\mathbf{0 . 8 5}$ & & & \\
AFCOM & 0.55 & $\mathbf{0 . 8 3}$ & & \\
CALCOM & 0.14 & 0.39 & $\mathbf{0 . 8 4}$ & \\
SRVREC & 0.64 & 0.49 & 0.14 & $\mathbf{0 . 7 5}$ \\
\hline
\end{tabular}

levels of trust and emotional attachment are related to customers' increased willingness to perform partnership activities and work together with the online travel agent.

Moreover, the findings of this study showed a nonsignificant negative relationship between calculative commitment and trust $(\mathrm{H} 2)$ (path coefficient $=-0.06$ ) and thus $\mathrm{H} 2$ was not supported. The results did not show any significant relationship between calculative commitment and trust. However, from the negative relationship obtained for $\mathrm{H} 2$ we might argue that when the state of attachment is experienced in terms of the benefits sacrificed and losses incurred if the relationship were to end, then the lower the degree of trust Gen Y will have to the travel vendor. In other words, when Gen Y commitment is based on attraction or moral obligation to stay in the relationship, it is clear that management should foster the former over the latter.

Research findings related to $\mathrm{H} 3$, which states that service recovery is positively associated with affective commitment, was significant (path coefficient $=0.51$ ). This outcome is consistent with the study of Tax et al. (1998). Consequently, this result emphasize the importance of service recovery efforts as a strategy to build ongoing long-term relationship with Gen Y customers and thus online travel agents should do their best to deliver successful service recovery as expected. Additionally, $\mathrm{H} 4$, which states that there is a positive relationship between service recovery and calculative commitment, was supported. Results related to $\mathrm{H} 4$ indicated that there is a significant positive relationship between service recovery and calculative commitment (path coefficient $=0.19$ ). As such, service recovery is important for both affective and calculative customers because it can enhance relationships. Clearly, from the standardized paths, service recovery's direct effect on affective commitment is stronger than its direct impact on calculative commitment. Finally, research findings related to $\mathrm{H} 5$ found that service recovery is positively associated with trust (path coefficient = 0.46). This study supports the positive relationship between service recovery and trust. In other words, the confidence in the reliability and dependability of travel service providers has positive effect on their intention to maintain relationships. 


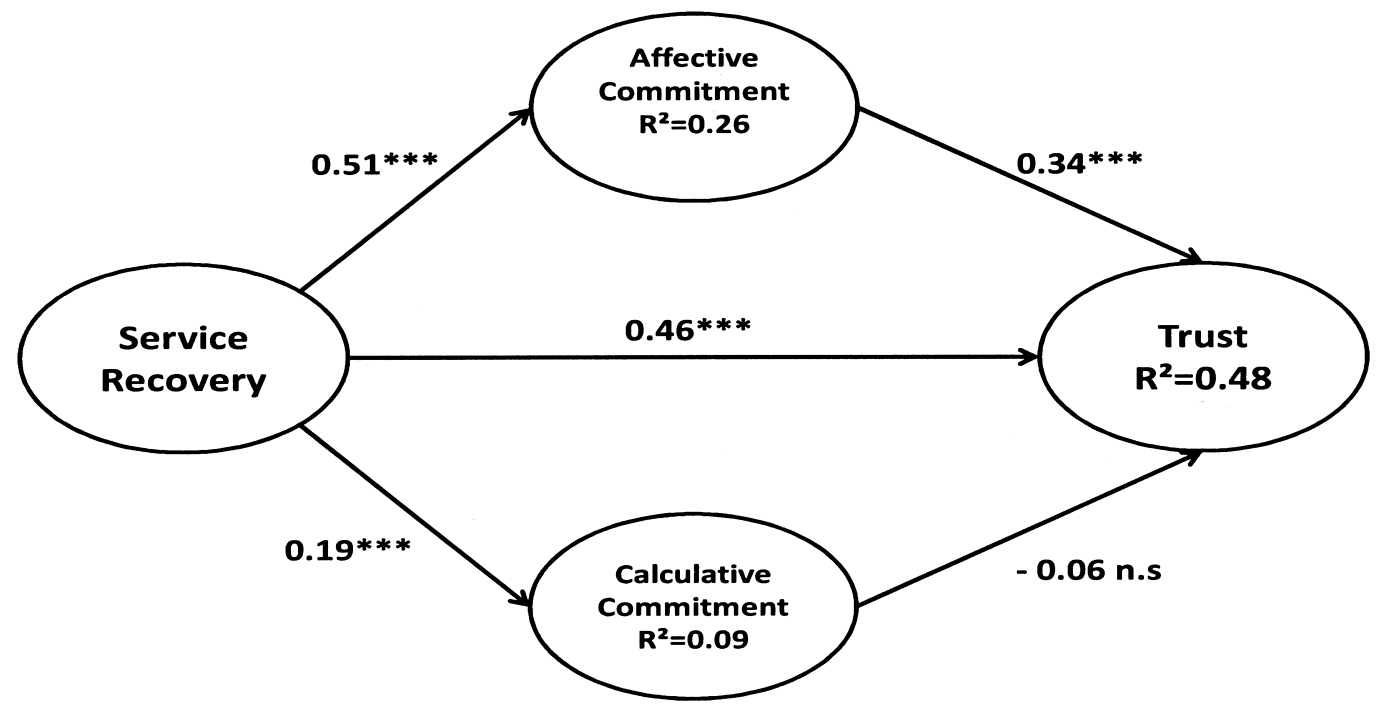

${ }^{*} \mathbf{p}<0.1 ;{ }^{* *} \mathbf{p}<0.05 ;{ }^{* * *} \mathbf{p}<0.01 ;$ n.s. non-significant

Figure 2. Final SEM model.

\section{Limitations and Implications for Research}

This research has a number of limitations, which constitute areas for future research. Firstly, the sample of this study is undergraduate students at a large Midwestern university. While college students are substantial segment of Gen Y, it would seem interesting to replicate this survey on a much more diversified sample of Gen $\mathrm{Y}$ consumers. Secondly, the focus of this study was online travel agents and results cannot be generalized to all types of e-travel vendors. Thirdly, we do not claim to have captured an exhaustive list of the antecedents and consequences of affective and calculative commitment. In order to develop a comprehensive model of relational commitment, future research may examine a larger number of antecedent constructs in addition to what has been examined in this study (e.g., switching costs, perceived utility, service quality, shopping motivation, etc.). Finally, in addition to trust, other outcome variables may be examined in future studies (attitude, word of mouth, purchase intention, etc.).

\section{Implications for Practice}

One of the main goals of the firms that operate through the Internet is to develop long-term relationships with their clients in order to succeed and achieve profitability. Overall, this research shows

Table 4

Standardized Path Coefficient and $t$-Value for the Structural Model

\begin{tabular}{lccc}
\hline Parameter Estimates Structural Paths & $\begin{array}{c}\text { Standardized } \\
\text { Path Coefficients }\end{array}$ & $t$-Value & $\begin{array}{c}\text { Hypotheses } \\
\text { Supported (Yes/No) }\end{array}$ \\
\hline $\mathrm{H} 1: \mathrm{AFCOM} \rightarrow(+)$ TRUST & 0.34 & $4.46^{* *}$ & yes \\
$\mathrm{H}$ 2: CALCOM $\rightarrow(-)$ TRUST & -0.06 & -1.00 & no \\
H3: SRVREC $\rightarrow(+)$ AFCOM & 0.51 & $5.75^{* *}$ & yes \\
H4: SRVREC $\rightarrow(+)$ CALCOM & 0.19 & $2.48^{*}$ & yes \\
H5: SRVREC $\rightarrow(+)$ TRUST & 0.46 & $5.19^{* *}$ & yes \\
\hline
\end{tabular}

${ }^{*} p<0.05 ; * * p<0.01$. 
that the appropriate service recovery measures will increase the level of affective commitment, calculative commitment, and trust of the Gen Y customer, which in return will improve the retention rate and profits of the travel business. The results indicate that Gen Y perceived affective commitment as the most important factor for developing long-term relationships. Affective commitment deals with having a sense of belongingness to the travel web vendor, feeling emotionally attached to the travel site, and believing that the vendor is the best alternative. Developing this type of commitment appears to be particularly important not only for ensuring the maintenance of the relationship, but also for enhancing it further. One strategy for improved affective commitment is to offer personalized features. To build social and psychological bonds with Gen Y customers, travel website designers should incorporate features that increase the sense of personal care and belonging for the website. Online communities such as chat rooms and discussion forums are examples of other strategies that help to enhance relational communication between a travel website and its Gen Y users. Participation in such online communities may increase an individual's perception of his/her personal linkage and emotional bond with the business. Once affective commitment to a website is developed, Gen Y customers will continue using the website in the future, recommend the website to other individuals, and defend the website when it is criticized.

Affective commitment and trust play such an essential role in customer relationships, marketers of travel websites are advised to emphasize activities and initiatives that promote positive feelings of affiliation and personal connection with the Gen Y customer. Long-term relationships with Gen Y customers can provide all kinds of advantages for e-travel suppliers. On the other hand, due to the negative impact of calculative commitment on trust, marketers of high-technology travel products are advised to emphasize functionalities that promote the need to stay in the relationship. For example, online travel agents can ensure a secure online system by using security features on the website because security is a significant determinant of trust. Overall, the findings of this study outline the distinction between affective commit- ment and calculative commitment because calculative commitment has significantly different effects on behavioral intentions than affective commitment. While affective commitment creates favorable intentions that help to preserve and reinforce the relationship, calculative commitment has the opposite effect. Marketers should implement marketing strategies that best satisfies the needs of both types of customers (affective and calculative).

In an ever-increasing competitive market, customer commitment and trust is a means by which online travel businesses will survive and prosper. In ensuring the customer is looked after, travel businesses need to give as much attention to ensuring that the service is delivered perfect the first time, as well as when there is a problem and a mechanism is in place to solve the issue, winning back the Gen Y customer. Offering superior service recovery and effectively bonding with the Gen Y customer leads to travel service providers' trust. Strong relationships were found to mitigate the effects of a poor recovery on a reduction of trust and commitment (Mattila, 2004). Having a deeper understanding of how service recovery influences affective commitment could aid managers in developing sound service recovery strategies. What might be considered an adequate recovery effort for a typical calculatively committed Gen Y customer (e.g., tangible compensation) does not seem enough for emotionally bonded customers. This finding implies that online travel organizations might need to develop customized service recovery strategies for each group of committed customers to eliminate the possibility of a service failure. For example, providing guarantees to customers that their personal information will be kept confidential, responding to customers email inquiries promptly, live customer service 24 by 7 to respond to customers questions are helpful service recovery strategies for calculatively committed customers.

\section{Biographical Note}

Dr. Khaldoon "Khal" Nusair joined Rosen College of Hospitality Management team in 2007. He earned his Ph.D. in Hospitality Management from The Ohio State University. He holds two Master of Science degrees both from The State University of New York at Stony Brook. Dr. Nusair's 
research interests include E-commerce and Information Systems. He is the author of one book and more than 20 refereed papers in leading academic journals and proceedings of international conferences.

\section{References}

Aladwani, A. (2001). Online banking: A field of drivers, developing challenges, and expectations. International Journal of Information Management, 21(3), 213-225.

Allen, N., \& Meyer, J. (1990). The measurement and antecedents of affective, continuance and normative commitment to organization. Journal of Occupational Psychology, 63(1), 1-8.

Andreassen, T. (2001). From disgust to delight: Do customers hold a grudge. Journal of Service Research, 4(1), 39-49.

Anderson, E., \& Weitz, B. (1992). The sue of pledges to build and sustain commitment in distribution channels. Journal of Marketing Research, 29, 18-34.

Bansal, H., Irving, P., \& Taylor, S. (2004). A three-component model of customer commitment to service providers. Journal of Academy of Marketing Science, 32(3), 109-250.

Bensley, J., \& Whitney, S. (2004). Generation shop. JB Research Company. Retrieved August 15, 2009, from http://www.jbresearchco.com/GenY.html

Berry, L. (1995). Relationship marketing of services: Growing interest, emerging perspective. Journal of Academy of Marketing Science, 23, 236-245.

Bies, R., \& Shapiro, D. (1987). Interactional fairness judgments: The influence of casual accounts. Social Justice Research, 1(2), 199-218.

Bitner, M., Brown, S., \& Meuter, M. (2000). Technology infusion in service encounters. Journal of the Academy of Marketing Science, 28(1), 138-149.

Blakewell, C., \& Mitchell, V. (2003). Generation Y female consumer decision-making styles. International Journal of Retail and Distribution Management, 31(2), 95-106.

Blodgett, J., Hill, D., \& Tax, S. (1997). The effect of distributive, procedural, and interactional justice on postcomplaint behavior. Journal of Retailing, 73(2), 185210.

Bowen, J., \& Shoemaker, S. (2003). Loyalty: A strategic commitment. Cornell Hotel and Restaurant Administration Quarterly, 39, 12-25.

Boyer, K., \& Hult, G. (2005a). Extending the supply chain: Integrating operations and marketing in the online grocery industry. Journal of Operations Management, 23(6), 642-661.

Buchanan, B. (1974). Building organizational commitment: The socialization of managers in work organizations. Administrative Science Quarterly, 19, 533-546.

Bue-Said, J. (2008, October 17). Educate yourself in the ways of the young. Travel Weekly (UK), 21.

Chen, P., \& Hitt, L. (2002). Measuring switching costs and the determinants of customer retention in Internet-enabled businesses: A study of the online brokerage industry. Information Systems Research, 13(3), 255-274.

Chi, C., \& Qu, H. (2008). Examining the structural rela- tionships of destination image, tourist satisfaction and destination loyalty: An integrated approach. Tourism Management, 29(4), 624-636.

Cox, B. (2002). Customer service still a struggle. Retrieved June 5, 2009, from http://dc.internet.com/news/print. $\mathrm{php} / 947951$

Cox, J., \& Dale, B. (2001). Service quality and e-commerce: An exploratory analysis. Managing Service Quality, 11(2), 121-131.

De Ruyter, K., Moorman, L., \& Lemmink, J. (2001). Antecedents of commitment and trust in customer-supplier relationships in high technology markets. Industrial Marketing Management, 30(3), 271-286.

Deutsch, M. (1975). Equity, equality, and need: What determines which value will be used as the basics of distributive justice. Journal of Social Issues, 31(3), 137149.

Dwyer, F., Schurr, H., \& Ho, S. (1987). Developing buyerseller relationships. Journal of Marketing, 51, 11-27.

Eastlick, M., Lotz, S., \& Warrington, P. (2006). Understanding online B-to-C relationships: An integrated model of privacy concerns, trust, and commitment. Journal of Business Research, 59, 877-886.

Forbes, L., Kelley, S., \& Hoffman, K. (2005). Typologies of e-commerce retail failures and recovery strategies. Journal of Services Marketing, 19(5), 280-292.

Fornell, C., \& Larcker, D. (1981). Evaluating structural equation models with unobservable variables and measurement error. Journal of Marketing Research, 18(1), $39-50$.

Fullerton, G. (2003). When does commitment lead to loyalty? Journal of Service Research, 5(4), 333-344.

Fullerton, G. (2005). The service quality-loyalty relationship in retail services; does commitment matter? Journal of Retailing and Consumer Services, 12(2), 99-111.

Garbarino, E., \& Johnson, M. (1999). The different roles of satisfaction, trust, and commitment in customer relationships. Journal of Marketing, 63, 70-87.

Gardyn, R. (2002). Educated consumers. American Demographics, 24(10), 18-19.

Geyskens, I., Steenkamp, E., Scheer, L., \& Kumar, N. (1996). The effects of trust and interdependence on relationship commitment: A trans-Atlantic study. International Journal of Research in Marketing, 13, 303-317.

Gilliland, D., \& Bello, D. (2002). The two sides to attitudinal commitment: The effect of calculative and loyalty commitment on enforcement mechanisms in distribution channels. Journal of the Academy of Marketing Science, 30(1), 24-43.

Goodwin, C., \& Ross, I. (1992). Customer response to service failure: Influence of procedural and interactional fairness perceptions. Journal of Business Research, 25(2), 149-163.

Grönroos, C. (1988). Service quality: The six criteria of good perceived service quality. Review of Business, 9(3), 10-13.

Hahn, J., Upchurch, R., \& Wang, Y. (2008). Millenial students, movies, and tourism. Tourism Analysis, 13(2), 189-204.

Hair, J., Anderson, R., Tatham, R., \& Black, W. (1998). 
Multivariate data analysis (5th ed.). Upper Saddle River, NJ: Prentice Hall.

Harrison-Walker, J. (2001). The measurement of word-ofmouth communication and an investigation of service quality and customer commitment as potential antecedents. Journal of Service Research, 4(1), 60-75.

Harteveldt, H. (2007, January). Trends 2007: Travel ecommerce. Forrester Trends.

Hess, R., Ganesan, S., \& Klein, N. (2003). Service failure and recovery: The impact of relationship factors on customer satisfaction. Journal of Marketing Science, 31(2), $127-145$.

Holloway, B., \& Beatty, S. (2003). Service failure in online retailing: A recovery opportunity. Journal of Service Research, 6(1), 92-105.

Huang, C., Chou, C., \& Lin, P. (2010). Involvement theory in constructing bloggers' intention to purchase travel products. Tourism Management, 31(4), 513-526.

Kelly, S., \& Davis, M. (1994). Antecedents to customer expectations for service recovery. Journal of the Academy of Marketing Science, 22(1), 52-61.

Kim, W., Han, J., \& Lee, E. (2001). The effects of relationship marketing on repeat purchase and word-of-mouth. Journal of Hospitality \& Tourism Research, 25(3), 272-288.

Kim, Y., Sullivan, P., \& Forney, J. (2007). Experiential retailing. New York: Fairchild Publications, Inc.

Lester, D., Forman, A., \& Loyd, D. (2005). Internet Shopping and buying behavior of college students. Services marketing Quarterly, 27(2), 123-138.

Lehto, X., Kim, D.-Y., \& Morrison, A. M. (2006). The effect of prior destination experience on online information search behavior. Tourism and Hospitality Research, $6,160-178$.

Mattila, A. (2004). The impact of service failures on customer loyalty: the moderating role of affective commitment. International Journal of Service Industry Management, 15(2), 134-149.

McCrindle, M. (2002). Understanding generation $Y$. The Australian Leadership Foundation.

McDougall, G., \& Levesque, T. (2000). Customer satisfaction with services: putting perceived value into the equation. Journal of Services Marketing, 14(5), 392410.

McKnight, D., \& Chervany, N. (2002). What trust means in e-commerce customer relationships: An interdisciplinary conceptual typology. Journal of Electronic Commerce, 6(2), 35-53.

Meyer, J., Allen, N., \& Smith, C. (1993). Commitment to organizations and occupations: Extension and test of a three-component conceptualization. Journal of Applied Psychology, 78(4), 538-551.

Mohammadian, A., \& Bekhor , S. (2008). Travel behavior of special population groups. Transportation, 35(5), 579-583.

Mohr, L., \& Bitner, M. (1995). The role of employee effort in satisfaction with service transactions. Journal of Business Research, 32(3), 239-252.

Mollenkopf, D., Rabinovich, E., Laseter, T., \& Boyer, K. (2007). Managing Internet product returns: A focus on effective service operations. Decision Sciences, 38(2), 215-250.

Molm, L., Takahashi, N., \& Peterson, G. (2000). Risk and trust in social exchange and experimental test of a classical proposition. American Journal of Psychology, 105(5), 1396-1427.

Morgan, R., \& Hunt, S. (1994). The commitment-trust theory of relationship marketing. Journal of Marketing, 58, 20-38.

Niedt, B. (2004). Calling Gen next; marketers target a population whose spending power will rival their boomer parents. The Post-Standard (Syracuse, NY), Business, CI.

O'Reilly, C., Chatman, J., \& Caldwell, D. (1991). People and organizational culture: A profile of comparison approach to assessing person-organization fit. Academy of Management Journal, 34(3), 487-516.

Oliver, R. (1999). Whence consumer loyalty. Journal of Marketing, 63(4), 33-44.

Parasuraman, A., Zeithaml, V., \& Malhorta, A. (2005). ES-QUAL A multiple-item scale for assessing electronic service quality. Journal of Service Research, 7(3), 213233.

Petre, M., Minocha, S., \& Roberts, D. (2006). Usability beyond the website: An empirically-grounded e-commerce evaluation instrument for the total customer experience. Behavior \& Information Technology, 25(2), 189-203.

Rao, V., \& Smith, B. (2005). Decision support in online travel retailing. Journal of Revenue \& Pricing Management, 5(1), 72-80.

Reed, C. (2007, February 5). Generation Y research: What makes ' $Y$ ' tick. Brand Strategy, 38.

Reisenwitz, T., \& Iyer, R. (2009). Differences in generation $\mathrm{X}$ and generation $\mathrm{Y}$ : Implications for the organization and marketers. Marketing Management Journal, 19(2), 91-103.

Schumacker, R., \& Lomax, R. (2004). A beginner's guide to structural equation modeling (2nd ed.). Hillsdale, $\mathrm{NJ}$ : Lawrence Erlbaum Associates.

Sharma, N., \& Patterson, P. (2000). Switching costs, alternative attractiveness and experience as moderators of relationship commitment in professional, consumer services. International Journal of Service Industry Management, 11(5), 470-490.

Singh, J. (1998). Consumer complaint intentions and behavior: Definitions and taxonomical issues. Journal of Marketing, 52(1), 93-107.

Sui, J., \& Baloglu, S. (2003). The role of emotional commitment in relationship marketing: An empirical investigation of a loyalty model for casinos. Journal of Hospitality \& Tourism Research, 27(4), 470-489.

Sullivan, P., \& Heitmeyer, J. (2008). Looking at Gen Y shopping preferences and intentions: Rxploring the role of experience and apparel involvement. International Journal of Consumer Studies, 32(3), 285-295.

Tax, S., \& Brown, W. (1998). Recovering and learning from service failure. Sloan Management Review, 40, 75-88.

Tax, S., Brown, W., \& Chandrashekran, M. (1998). Cus- 
tomer evaluations of service complaint experiences: Implications for relationship marketing. Journal of Marketing, 62, 60-76.

Teeter, C., \& Schointuch, B. (2000). Controlling Internet service quality. Credit Union Executive Journal, 40(6), 6-11.

Thorbjornsen, H., Supphellen, M., Nysveen, H. \& Pedersen, P. (2002). Building brand relationship online: A comparison of two interactive applications. Journal of Interactive Marketing, 16(3), 17-34.

Thibaut, J., \& Walker, L. (1975). Procedural justice: A psychological analysis. Hillsdale, NJ: Lawrence Erlbaum Associates.

Thirumalai, S., \& Sinha, K. (2005). Customer satisfaction with order fulfillment in retail supply chains: Implica- tions of product type in electronic B2C transactions. Journal of Operations Management, 23(3/4), 291-303.

Weiss, M. (2003). To be about to be. American Demographics, 25, 29-36.

Wolburg, J., \& Pokrywczyniski, J. (2001). A psychographic analysis of Generation Y college students. Journal of Advertising Research, 41, 3-52.

Wong, A., \& Sohal, A. (2002). An examination of the relationship between trust, commitment and relationship quality. International Journal of Retail \& Distribution Management, 30(1), 34-51.

Yin, S. (2003). Degree of challenge. American Demographics, 25(4), 20-22.

Young compulsive shoppers booming. (2009, Janaury 30). McClatchy-Tribune Business News. 